\title{
INVERSE PROBLEM FOR HILL EQUATION WITH JUMP CONDITIONS
}

\author{
Hikmet Koyunbakan ${ }^{1}$ \\ ${ }^{1}$ Firat University
}

March 16, 2021

\section{Hosted file}

Koyunbakan.pdf available at https://authorea.com/users/360779/articles/491805-inverseproblem-for-hill-equation-with-jump-conditions 